\title{
Analisis Akurasi Multivariate Discriminant Analysis (MDA) Altman Dalam Memprediksi Kebangkrutan Perusahaan Di Bursa Efek Indonesia
}

Oleh

\author{
Komang Agus Rudi Indra Laksmana
}

Abstrak

Multivariate Discriminant Analysis (MDA) model Altman atau yang sering disebut dengan MDA Altman merupakan salah satu alat analisis di dalam memprediksi kebangkrutan perusahaan melalui kombinasi persamaan rasio likuiditas, profitabilitas, leverage dan aktivitas. Selain sebagai alat analisis, persamaan MDA Altman juga dipergunakan untuk mencirikan atau membedakan satu group perusahaan dengan group perusahaan lainnya. Dari tahapan tehnik analisa data diperoleh hasil yakni terdapat perbedaan kinerja keuangan antara perusahaan delist dan non-delist berdasarkan perhitungan MDA Altman serta diperoleh tingkat keakuratan MDA Altman dalam memprediksi kesulitan keuangan dan kebangkrutan suatu perusahaan untuk mendiskriminasikan 2 group perushaaan (delist dan non-delist) tingkat akurasi mencapai rata-rata 90\%. Sehingga dapat dikatakan bahwa persamaan MDA Altman yang diteliti dalam penelitian ini layak untuk digunakan memprediksi kesulitan dan kebangkrutan perusahaan

Kata Kunci: Analisis Akurasi, Uji Beda, MDA Altman

\section{PENDAHULUAN}

Bursa efek adalah merupakan sebuah fasilitas tempat bertemunya perusahaan dengan investor dalam rangka memperoleh modal. Di dalam bursa efek terjadi hubungan timbal balik antara investor dengan emiten, dimana investor menanamkan modalnya pada perusahaan dengan maksud untuk mendapatkan keuntungan sementara perusahaan memperoleh tambahan modal untuk ekspansi ataupun operasi perusahaan. Namun, satu hal penting yang harus diperhatikan oleh investor sebelum melakukan investasi terhadap perusahaan tertentu, perlu dilakukan prediksi dan perhitungan untuk menghindari kerugian yang bisa terjadi di kemudian hari. 
Menurut Casterela, Lewis dan Walker (2000) model prediksi kebangkrutan pada umumnya terdiri dari tiga, yakni The Zmijewski Model, The Altman Model dan The Springate Model. Menurut penelitian Sharma dan Sindhu (2001) menyatakan bahwa The Altman Model memiliki tingkat keakuratan yang paling tinggi diantara ketiga model prediksi kebangkrutan tersebut. Pendapat ini juga didukung oleh beberapa penelitian diantaranya Mc.Keown (1991), Dopach (1987) dan Peel (1989). Menurut Emery (2004:844) menyatakan bahwa Multivariate Discriminates Analysis (MDA) model Altman atau sering disebut dengan Z-score Altman merupakan salah satu alat analisis yang bisa dipergunakan untuk menilai kinerja keuangan. Uji keakuratan MDA ini sudah cukup banyak diteliti oleh beberapa peneliti. Terdapat beberapa penelitian yang telah dilakukan oleh beberapa peneliti untuk uji keakuratan dalam suatu penelitian, salah satunya adalah penelitian dari Inge Agustine (2001) yang meneliti 24 perusahaan dengan 7 perusahaan financial berupa bank yang terdaftar di Bursa Efek Jakarta

Pada penelitian ini akan mencoba untuk menguji sejauh mana MDA Altman mampu membedakan kelompok populasi perusahaan yang delist dan non-delist di Bursa Efek Indonesia. Perusahaan yang mengalami delist pada tahun 2007 pada Bursa Efek Indonesia merupakan perusahaan yang memiliki tingkat earning before interest and tax selama 2 tahun berturut-turut dan nilai working capital yang negatif selama 2 tahun berturut-turut, sehingga dari 9 perusahaan yang mengalami delist pada tahun 2007, ternyata 5 perusahaan yang mengalami indikasi kebangkrutan dengan dua kriteria tersebut diatas perusahaan tersebut yakni PT. Mulialand Tbk, PT. Suba Indah Tbk, PT. Surya Dumai Industri Tbk, PT. Texmaco Jaya Tbk dan PT. Bahtera Adimina Samudra Tbk. Dan untuk perusahaan pembandingnya juga disertakan 5 perusahaan yang non-delist yang memiliki ruang likup usaha yang sejenis dengan perusahaan yang mengalami delist, perusahaan non-delist tersebut yakni PT. Bhakti Investama Tbk, PT. Enseval Putera Megatrading Tbk, PT. Astra Agro Lestari Tbk, PT. Roda Vivatex Tbk dan PT. FKS Multi Agro Tbk. Sehingga total perusahaan yang menjadi subjek penelitian ini adalah sebanyak 10 perusahaan yang terbagi dalam 2 group perusahaan yakni group perusahaan yang delist dan group perusahaan yang non-delist.

Untuk penelitian ini akan menggunakan lima persamaan rasio keuangan yang dikombinasikan dengan persamaan baku MDA Altman yakni current ratio, returnt of investmen, net profit margin, operating cash flow dan net sales ratio. Untuk perhitungan masing-masing rasio keuangan tersebut maka diperoleh sumber informasinya dari laporan 
keuangan kesepuluh perusahaan delist dan non-delist tersebut selama periode tahun 2003 sampai dengan tahun 2006.

Berdasarkan latar belakang tersebut diatas maka dapat ditentukan rumusan masalah dalam penelitian ini yakni "Apakah terdapat perbedaan kinerja keuangan antara kelompok perusahaan yang delist dan kelompok perusahaan yang non-delist pada Bursa Efek Indonesia tahun 2007 melalui perhitungan persamaan MDA Altman yang digunakan dalam penelitian ini?"

\section{KAJIAN PUSTAKA DAN RUMUSAN HIPOTESIS}

\section{Multivariate Discriminant Analysis Model Altman}

Luciana (2003:3) menjelaskan bahwa Multivariate Discriminant Analysis Altman atau yang biasa disebut Z-score Model Altman menggunakan rasio keuangan yang mencakup rasio likuiditas perusahaan seperti rasio lancar, rasio leverage perusahaan seperti rasio hutang terhadap modalnya, rasio profitabilitas seperti rasio laba bersih terhadap modal atau akumulasi laba ditahan. Dengan mendasarkan rasio kepada rasio keuangan tersebut, Z-score Model Altman berhasil dipergunakan untuk mengklasifikasikan perusahaan kedalam kelompok yang mempunyai kemungkinan yang tinggi untuk bangkrut atau kelompok perusahaan yang kemungkinan mengalami bangkrut rendah. Z-score Model Altman memungkinkan untuk memperkirakan kebangkrutan sampai dua tahun sebelum tiba saatnya.

Menurut penelitian Departemen Keuangan Indonesia (2005:18). Terdapat dua formula yang dihasilkan dari penjabaran persamaan Z-score Altman:

1. Formula Z Score untuk Perusahaan Publik (Terbuka) adalah:

$\mathrm{Z}=1,2 \mathrm{~A}+1,4 \mathrm{~B}+3,3 \mathrm{C}+0,6 \mathrm{D}+1,0 \mathrm{E}$

Sehat jika Z > 2,99; Grey area jika 1,81 < Z <2,99; Tidak Sehat jika $Z<1,81$

Keterangan:

$\mathrm{Z}=$ nilai hasil perhitungan

$\mathrm{A}=$ modal kerja / Total Aktiva

$\mathrm{B}=$ Saldo Laba / Total Aktiva

$\mathrm{C}=$ Laba sebelum Beban Bunga dan Pajak / Total Aktiva

$\mathrm{D}=$ Nilai pasar dari Ekuitas / Total Kewajiban

$\mathrm{E}=$ Total Pendapatan atau Penjualan / Total Aktiva

2. Formula Z Score untuk Perusahaan Tertutup adalah :

$Z=0,717 \mathrm{~A}+0,847 \mathrm{~B}+3,107 \mathrm{C}+0,420 \mathrm{D}+0,99 \mathrm{E}$

$\mathrm{Z}=$ nilai hasil perhitungan

$\mathrm{A}=$ modal kerja / Total Aktiva 
$\mathrm{B}=$ Saldo Laba / Total Aktiva

$\mathrm{C}=$ Laba sebelum Beban Bunga dan Pajak / Total Aktiva

$\mathrm{D}=$ Book value of preferred and common equity/ Total Kewajiban

$\mathrm{E}=$ Total Pendapatan atau Penjualan / Total Aktiva

Sehat jika Z $>2,90$; Grey area jika 1,20 $<Z<2,90$; Tidak Sehat jika $Z<1,20$

\section{Rumusan Hipotesis}

1. H1: Terdapat perbedaan kinerja keuangan antara kelompok perusahaan yang delist dengan kelompok perusahaan yang non-delist melalui perhitungan persamaan MDA Altman.

2. H0: Tidak Terdapat perbedaan kinerja keuangan antara kelompok perusahaan delist dengan kelompok perusahaan non-delist melalui perhitungan persamaan MDA Altman

\section{METODE PENELITIAN}

Populasi dalam penelitian ini adalah seluruh perusahaan yang mengalami delist dan non-delist pada Bursa Efek Indonesia tahun 2007. Periode laporan keuangan yang digunakan dalam penelitian ini adalah sejak tahun 2003 sampai dengan tahun 2006. Sampel dalam penelitian ini dipilih dengan menggunakan metode judgment sampling, yaitu suatu metode penentuan sampel berdasarkan kriteria tertentu yang telah ditentukan sebelumnya oleh peneliti. Dari semua perusahaan yang mengalami delist, dipilih 5 perusahaan yang dianggap dapat mewakili perusahaan delist yang benar-benar mengalami indikasi kebangkrutan. Dan dipilih 5 perusahaan non-delist sebagai pembanding yang memiliki ruang lingkup usaha yang relatif sama dengan perusahaan yang delist. Sumber data dalam penelitian ini adalah laporan keuangan kesepuluh perusahaan delist dan non-delist pada tahun 2007 periode tahun 2003 sampai dengan 2006 yang telah dipublikasikan melalui website Bursa Efek Indonesia.

Variabel rasio keuangan yang digunakan dalam penelitian ini terdiri dari current ratio, returnt on investmen, net profit margin, operating cash flow dan net sales ratio.

\section{Current Ratio}

Rasio ini digunakan untuk mengukur kemampuan perusahaan memenuhi kewajiban jangka pendeknya. Rasio yang digunakan dalam penelitian ini menggunakan current ratio (rasio lancar). Dasar dari penggunaan rasio ini menurut Munawir $(2001 ; 225)$ adalah survey tingkat responden terhadap penggunaan rasio keuangan dalam penelitian yang menempatkan current ratio sebagai rasio likuiditas yang memiliki significance rating sebesar 8,25 yang termasuk kategori rasio yang sangat penting. Dengan persamaan sebagai berikut; 


\section{Current ratio $=\quad$ current asset \\ current liabilities}

\section{Return On Investment (ROI)}

Return On Investment (ROI) menggambarkan kemampuan perolehan laba bersih dalam mengembalikan total investasi. menurut Munawir $(2001 ; 225)$ menyebutkan bahwa rasio ROI memiliki significance rating 7,43 yang termasuk kategori rasio yang sangat penting digunakan oleh para peneliti, dengan persamaan sebagai berikut:

$$
\mathrm{ROI}=\underline{\text { net profit }}
$$

\section{Net Profit Margin (NPM)}

total asset

Net profit margin merupakan rasio yang menggambarkan kemampuan penjualan bersih mampu memberikan keuntungan bersih terhadap perusahaan yang bersangkutan. Rasio ini diperoleh dengan menggunakan rumus sebagai berikut:

NPM $=$ net profit

$$
\text { net sales }
$$

\section{Operating Cash Flow Ratio}

Operating cash flow ratio menggambarkan penggunaan total hutang untuk kegiatan operasional. Menurut Munawir $(2001 ; 225)$ adalah survey tingkat responden terhadap penggunaan rasio keuangan dalam penelitian yang menempatkan cash flow total debt sebagai debt ratio yang memiliki significance rating sebesar 8,08 yang termasuk kategori rasio yang sangat penting. Sehingga dapat dirumuskan sebagai berikut;

Operating cash flow ratio $=$ operating cash flow

$$
\text { total debt }
$$

\section{Asset Turnover Ratio}

Asset turnover ratio menggambarkan kemampuan perusahaan dalam mengoptimalkan seluruh aset yang dimilikinya. Dengan persamaan rasio sebagai berikut;

$$
\text { Asset turnover ratio }=\frac{\text { net sales }}{\text { total asset }}
$$

\section{Multivariate Discriminant Analysis Model Altman}

Model yang digunakan dalam menganalisis penelitian ini adalah Z-score Altman. Multivariate Discriminant Analysis Altman digunakan untuk mengklasifikasikan perusahaan bangkrut dan tidak bangkrut, namun khusus pada penelitian ini digunakan 
istilah perusahaan yang delist dan perusahaan yang non-delist. Adapun persamaan MDA Altman adalah sebagai berikut:

$$
\mathrm{Z}=1.2 \mathrm{~A}+1.4 \mathrm{~B}+3.3 \mathrm{C}+0.6 \mathrm{D}+1.0 \mathrm{E}
$$

Dimana

$\mathrm{Z}=$ nilai diskriminan perusahaan delist dan non-delist tahun 2003-2006.

$\mathrm{A}-\mathrm{E}=$ variabel-variabel bebas dengan persamaan

$\mathrm{A}=$ current assets/current liabilities perusahaan delist dan non-delist tahun 20032006.

$\mathrm{B}=$ net profit/total asset perusahaan delist dan non-delist tahun 2003-2006.

$\mathrm{C}=$ net proft/net sales perusahaan delist dan non-delist tahun 2003-2006.

$\mathrm{D}=$ operating cash flow/total debt perusahaan delist dan non-delist tahun 20032006

$\mathrm{E}=$ net sales/total asset perusahaan delist dan non-delist tahun 2003-2006

Ketentuan: Non-delist jika Z $>2,99$; Delist jika Z $<2,99$

\section{Independent Sample T-test}

Uji-T digunakan untuk menguji rata-rata satu group sampel berbeda dengan satu group sampel lainnya. Penggunaan metode Uji-T berdasarkan pada jumlah sampel pada penelitian dalam jumlah kecil $(\mathrm{n}<30)$. Dengan rumus sebagai berikut:

$$
\begin{aligned}
& r=\sqrt{n-2} \\
& r=\sqrt{1-r^{2}}
\end{aligned}
$$

Dimana :

$$
\begin{aligned}
\mathrm{T} & =\text { test } \\
\mathrm{r} & =\text { korelasi } \\
\mathrm{n} & =\text { jumlah sample }
\end{aligned}
$$

Pada penelitian ini yang menggunakan jumlah sampel kecil (10 perusahaan) akan diteliti 2 group perusahaan yakni pertama yaitu perusahaan delist sebanyak 5 perusahaan dan group kedua yakni perusahaan non-delist sebanyak 5 perusahaan. Variabel yang diteliti dalam penelitian ini adalah nilai z yang diperoleh dalam perhitungan persamaan diskriminan analisis model Altman serta perhitungan laporan keuangan 2 group perusahaan periode tahun 2003-2006. Dasar dari pengambilan keputusan untuk menilai maka ditetapkan pengambilan keputusan sebagai berikut:

- Jika probabilitas nilai z memiliki Sig $>0,05$, maka tidak terdapat perbedaan kinerja keuangan antara perusahaan delist dan non-delist di Bursa Efek Indonesia tahun 2007 berdasarkan perhitungan persamaan MDA Altman yang ditetapkan dalam penelitian ini. 
- Jika probabilitas nilai z memiliki Sig $<0,05$, maka terdapat perbedaan kinerja keuangan antara perusahaan delist dan non-delist di Bursa Efek Indonesia tahun 2007 berdasarkan perhitungan persamaan MDA Altman yang ditetapkan dalam penelitian ini.

\section{PEMBAHASAN}

Perusahaan yang termasuk dalam kategori delist dalam penelitian ini adalah sebanyak 5 perusahaan non-financial yang delisting di Bursa Efek Indonesia tahun 2007 dan perusahaan pembanding non-delist sebanyak 5 perusahaan non-financial yang memiliki ruang lingkup usaha yang relatif sama dengan perusahaan yang mengalami delist pada tahun 2007 di Bursa Efek Indonesia. Berikut ini akan ditampilkan hasil perhitungan MDA Altman terhadap laporan keuangan kesepuluh perusahaan delist dan non-delist periode tahun 2003 sampai dengan tahun 2006 berdasarkan pada persamaan MDA Altman yang ditetapkan dalam penelitian ini.

\section{Hasil Perhitungan MDA Altman periode tahun 2003-2006}

Berdasarkan perhitungan persamaan MDA Altman

$\mathrm{Z}=1.2 \mathrm{~A}+1.4 \mathrm{~B}+3.3 \mathrm{C}+0.6 \mathrm{D}+1.0 \mathrm{E}$

Diperoleh nilai z untuk masing-masing perusahaan delist dan non-delist periode tahun 2003 samapi dengan tahun 2006 sebagai berikut;

\begin{tabular}{|c|c|c|c|c|}
\hline \multirow{2}{*}{$\begin{array}{c}\text { No.Urut } \\
\text { Perusahaan }\end{array}$} & \multicolumn{4}{|c|}{ Nilai z persamaan MDA Altman } \\
\cline { 2 - 5 } & 2003 & 2004 & 2005 & 2006 \\
\hline 1 & -1.918 & -1.398 & -0.643 & 1.267 \\
\hline 2 & -0.229 & -0.566 & -5.242 & -4.574 \\
\hline 3 & 2.671 & -0.283 & -1.307 & -2.477 \\
\hline 4 & -1.319 & -8.031 & -7.418 & -1.633 \\
\hline 5 & 1.711 & -0.598 & $-0,336$ & 0.612 \\
\hline 6 & 3.975 & 2.697 & 2.463 & 3.190 \\
\hline 7 & 4.842 & 5.074 & 5.592 & 5.684 \\
\hline 8 & 3.299 & 4.241 & 5.180 & 4.068 \\
\hline 9 & 5.746 & 4.036 & 2.937 & 2.312 \\
\hline 10 & 8.390 & 8.409 & 6.689 & 6.995 \\
\hline
\end{tabular}

Ket; No urut 1-5 perusahaan delist, no urut 6-10 perusahaan non-delist

\section{Hasil Perhitungan Uji Beda Independent Sample T-test}

Dari nilai $\mathrm{z}$ masing-masing perusahaan delist dan non-delist diatas maka selanjutnya dilakukan perhitungan uji beda dengan persamaan independent sample t-test, 
untuk perhitungan dibantu dengan program SPSS versi 11.5 for windows. Hasil perhitungan independent sample t-test periode tahun 2003 sampai dengan tahun 2006 sebagai berikut;

\section{Hasil perhitungan independent sample t-test tahun 2003}

\begin{tabular}{|c|c|c|c|c|}
\hline $\begin{array}{c}\text { Levene test for equality } \\
\text { of variances }\end{array}$ & \multicolumn{3}{|c|}{$t$-test for equality of means } \\
\hline$F$ & Sig & $t$ & $d f$ & Sig (2-tailed) \\
\hline 0,061 & 0,811 & $-4,066$ & 8 & 0,004 \\
& & & & \\
\hline
\end{tabular}

Dari tabel diatas dapat diketahui bahwa nilai t hitung sebesar -4,066 dengan nilai signifikan (2-tailed) sebesar 0,004 atau $<0,05$, sehingga dapat disimpulkan bahwa pada tahun 2003 terdapat perbedaan kinerja keuangan antara kelompk perusahaan delist dengan kelompok perusahaan non-delist di Bursa Efek Indonesia. Ini ditunjukan dengan nilai Sig (2-tailed) $0,004<0,05$.

\section{Hasil perhitungan independent sample t-test tahun 2004}

\begin{tabular}{|c|c|c|c|c|}
\hline $\begin{array}{c}\text { Levene test for equality } \\
\text { of variances }\end{array}$ & \multicolumn{3}{|c|}{$t$-test for equality of means } \\
\hline$F$ & Sig & $t$ & $d f$ & Sig (2-tailed) \\
\hline 0,632 & 0,450 & $-4,016$ & 8 & 0,004 \\
\hline
\end{tabular}

Dari tabel tersebut diketahui bahwa nilai t hitung pada tahun 2004 sebesar $-4,016$ dengan nilai signifikan (2-tailed) sebesar 0,004 atau < 0,05 sehingga dapat disimpulkan bahwa pada tahun 2004 terjadi perbedaan kinerja keuangan antara perusahaan delist dengan perusahaan non-delist di Bursa Efek Indonesia. Ini ditunjukan dengan nilai signifikan (2tailed) sebesar $0,004<0,05$.

Hasil Perhitungan indepenent sample t-test tahun 2005

\begin{tabular}{|c|c|c|c|c|}
\hline $\begin{array}{c}\text { Levene test for equality } \\
\text { of variances }\end{array}$ & \multicolumn{3}{|c|}{$t$-test for equality of means } \\
\hline$F$ & Sig & $t$ & $d f$ & Sig (2-tailed) \\
\hline 3,204 & 0,111 & $-3,743$ & 8 & 0,006 \\
\hline
\end{tabular}

Dari tabel tersebut diketahui bahwa nilai t hitung pada tahun 2005 sebesar $-3,743$ dengan nilai signifikan (2-tailed) sebesar 0,006 atau < 0,05 sehingga dapat disimpulkan bahwa pada tahun 2005 terjadi perbedaan kinerja keuangan antara perusahaan delist dengan 
perusahaan non-delist di Bursa Efek Indonesia. Ini ditunjukan dengan nilai signifikan (2tailed) sebesar $0,006<0,05$.

Hasil Perhitungan independent sample t-test tahun 2006

\begin{tabular}{|c|c|c|c|c|}
\hline $\begin{array}{c}\text { Levene test for equality } \\
\text { of variances }\end{array}$ & \multicolumn{3}{|c|}{$t$-test for equality of means } \\
\hline$F$ & Sig & $t$ & $d f$ & Sig (2-tailed) \\
\hline 0,258 & 0,625 & $-4,287$ & 8 & 0,003 \\
\hline
\end{tabular}

Dari tabel tersebut diketahui bahwa nilai t hitung pada tahun 2006 sebesar $-4,287$ dengan nilai signifikan (2-tailed) sebesar 0,003 atau < 0,05 sehingga dapat disimpulkan bahwa pada tahun 2006 terjadi perbedaan kinerja keuangan antara perusahaan delist dengan perusahaan non-delist di Bursa Efek Indonesia. Ini ditunjukan dengan nilai signifikan (2tailed) sebesar $0,003<0,05$.

\section{KESIMPULAN}

Bahwa terdapat perbedaan kinerja keuangan diantara kedua kelompok perusahaan delist dan perusahaan non-delist di Bursa Efek Indonesia pada tahun 2007 berdasarkan perhitungan persamaan MDA Altman yang ditetapkan dalam penelitian ini. Ini ditunjukan dari nilai signifikan (2-tailed) dari tahun 2003 sampai dengan tahun 2006 memiliki nilai signifikan $(2$-tailed $)<0,05$ melalui perhitungan independent sampel t-test dengan bantuan program SPSS versi 11.5 for windows, dengan tingkat signifikan sebesar $5 \%(0,05)$ diperoleh hasil perhitungan independent sample t-test dari tahun 2003 sampai dengan tahun 2006 yang ditunjukan pada tabel berikut ini;

\begin{tabular}{|c|c|c|c|}
\hline Tahun & $t$ & $d f$ & Sig (2-tailed) \\
\hline 2003 & $-4,066$ & 8 & 0,004 \\
2004 & $-4,016$ & 8 & 0,004 \\
2005 & $-3,743$ & 8 & 0,006 \\
2006 & $-4,287$ & 8 & 0,003 \\
\hline
\end{tabular}

\section{SARAN}


Dalam penelitian ini hanya menggunakan 10 perusahaan sebagai subjek penelitian. Diharapkan pada penelitian selanjutnya dapat menambah jumlah subjek penelitian untuk menghasilkan penelitian yang lebih akurat.

Penelitian ini masih menggunakan program SPSS 11.5 for windows, untuk penelitian selanjutnya diharapkan analisi uji beda dapat menggunakan program SPSS terbaru atau AMOS.

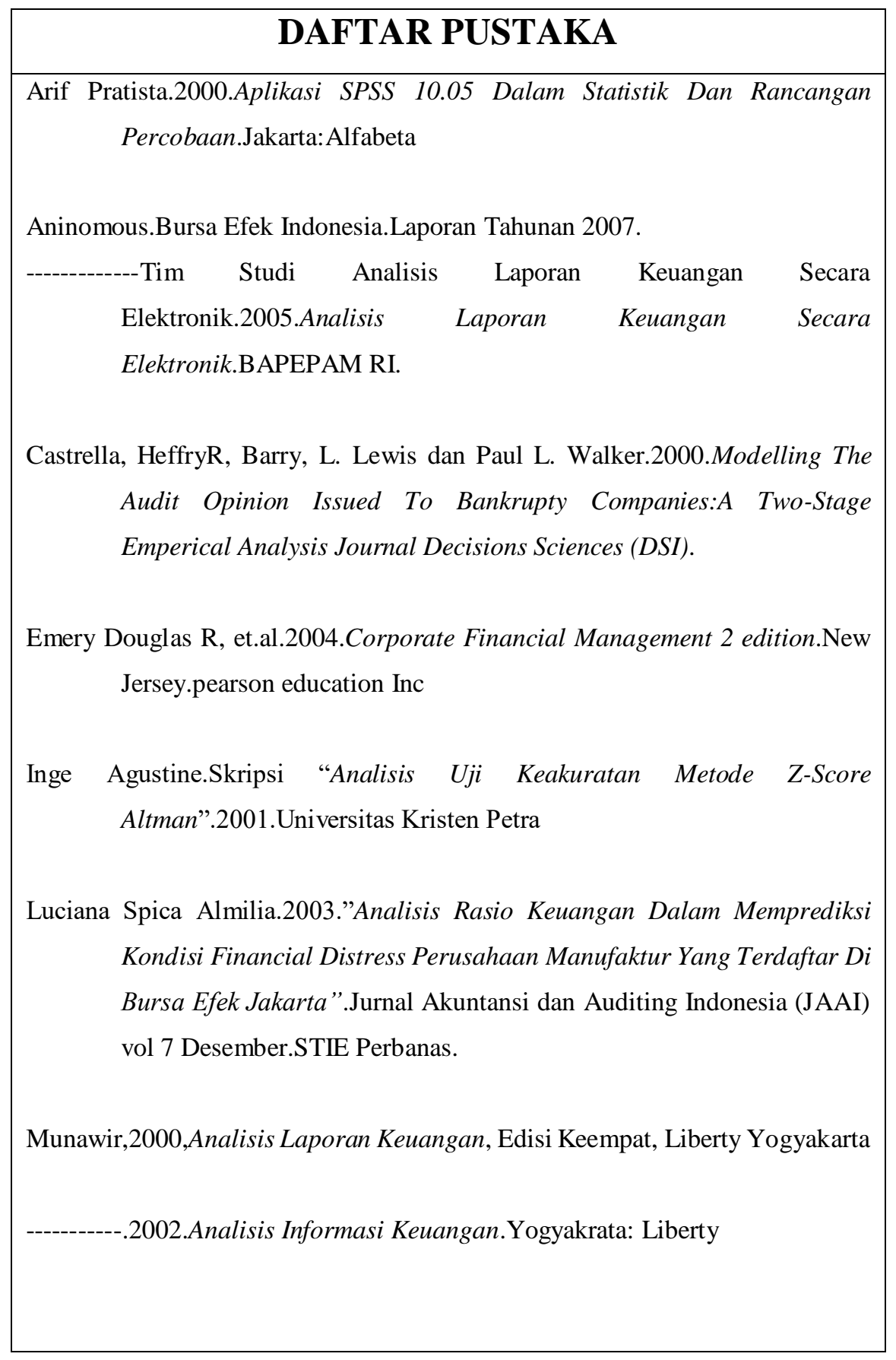


